\title{
NILAI FINANSIAL DAN POTENSI KONFLIK PERIKANAN UDANG MANTIS DI KUALA TUNGKAL, JAMBI
}

\author{
FINANCIAL VALUE AND POTENTIAL CONFLICT OF MANTIS SHRIMP \\ IN KUALA TUNGKAL, JAMBI
}

\author{
Nofrizal", Farhan Ramdhani, \& Romie Jhonnerie \\ Fakultas Perikanan dan Kelautan, Universitas Riau, Pekanbaru, 28293, Indonesia \\ *E-mail: aan_fish@yahoo.com
}

\begin{abstract}
Mantis shrimp is an export commodity that caught by fishermen in Kuala Tungkal. Mostly, the fishermen use gillnet as their main fishing gear. However, this fishing effort shares open access and common property to be its aquatic resources with other fishing businesses that may bring potential conflicts related to fishing areas, utilization of aquatic resources, fishing gear, etc. Thus, this current study aims to analyze economic value and potential conflicts in mantis shrimp catch in Kuala Tungkal. A survey method was applied as the research method. From 2015 to 2017, the export volume and value of shrimp commodities continued to increase. The results show that profit value $(\pi)$ possessed by catching mantis shrimp is Rp637.500,00 per trip, R/C 5.6 and PP 39 trips showing a good financial value and potential to be developed. Meanwhile, potential conflicts in catching mantis shrimp tend to be low since there is no overlapping fishing area for each fishing gear operated by different aquatic resource users. It means that the operation of fishing gear has been set well by the community of fishing businesses in that area so that the potential for social conflicts between aquatic resources users is also low.
\end{abstract}

Keywords: financial value, gillnet, mantis shrimp, potential conflict

\begin{abstract}
ABSTRAK
Udang mantis (Harpiosquilla rapidhea) merupakan komoditas ekspor hasil tangkapan nelayan dengan alat tangkap gillnet di Kuala Tungkal yang memiliki nilai ekonomi tinggi. Penangkapan udang mantis di perairan Kuala Tungkal menjadi sebuah entitas usaha yang memanfaatkan sumberdaya perairan yang bersifat open access (terbuka untuk dimanfaatkan) dan common property (sumberdaya milik bersama), sehingga para pelaku usaha penangkapan udang mantis harus berhadapan dengan berbagai pelaku usaha penangkapan lain yang memiliki pemanfaatan sumberdaya berbeda terhadap wilayah perairan yang sama. Kondisi tersebut memunculkan berbagai potensi konflik terkait pembagian wilayah penangkapan, pemanfaatan sumberdaya perairan (hasil tangkapan), penggunaan alat tangkap dan lain sebagainya. Penelitian ini bertujuan untuk menduga nilai finansial serta potensi konflik yang mungkin ditimbulkan dari penangkapan udang mantis. Metode yang digunakan adalah metode survei. Dalam kurun waktu 2015 sampai dengan 2017, volume ekspor dan nilai komoditas udang mantis terus mengalami peningkatan. Nilai keuntungan usaha $(\pi)$ yang dimiliki oleh penangkapan udang mantis sebesar Rp637.500,00 per trip, R/C 5,6 dan PP 39 trip. Berdasarkan hasil tersebut maka penangkapan udang mantis memiliki kelayakan nilai finansial serta dapat dikembangkan. Potensi konflik usaha penangkapan udang mantis cenderung rendah. Hal tersebut ditunjukkan dengan tidak ditemukan adanya wilayah penangkapan yang sama untuk setiap alat tangkap yang beroperasi, penggunaan alat tangkap tidak mengganggu hasil tangkapan pada alat tangkap lain serta ketergangguan secara sosial dari penangkapan udang mantis dengan alat tangkap lain cenderung rendah.
\end{abstract}

Kata kunci: gillnet, nilai finansial, potensi konflik, udang mantis 


\section{PENDAHULUAN}

Penangkapan udang mantis $(H$. raphidea) di Perairan Kuala Tungkal, Kabupaten Tanjung Jabung Barat berkembang pesat belakangan ini. Hal ini dikarenakan potensi komoditas perikanan tersebut cukup besar. Selain itu nilai jual komoditas ini cukup tinggi jika dibandingkan dengan komoditas perikanan lainnya. Dahuri (2003) melaporkan 60\% komoditas ekspor di bidang perikanan merupakan jenis crustacean dan udang, dengan negara tujuan utama ekspor adalah Taiwan, Hongkong dan China. Selanjutnya, Rudiana \& Pringgenies (2004) menyatakan bahwa komoditas udang merupakan komoditas unggulan di tanah air. Komoditas ini merupakan komoditas nomor dua setelah komoditas ikan.

Beberapa daerah di Provinsi Riau, seperti Kabupaten Bengkalis dan Indragiri Hilir, udang mantis tidak memiliki nilai ekonomis. Komoditas ini merupakan hasil tangkapan sampingan bahkan dibuang kembali ke laut menjadi discard (Nofrizal et al., 2018). Hal ini disebabkan belum terbukanya pangsa pasar lokal ataupun pedagang pengumpul yang dapat menampung komoditas perikanan udang mantis ini. Di sisi lain perairan Kuala Tungkal, udang mantis merupakan komoditas dengan nilai ekonomis tinggi. Selanjutnya seperti dilaporkan Wardiatno et al. (2014) pada tahun 2003-2009 permintaan udang mantis terus meningkat yang mencapai 125.000-225.000 ekor/tahun. Operasi penangkapan udang mantis di Kuala Tungkal dapat dilakukan sepanjang hari tanpa mengenal musim.

Keberlangsungan dan keberlanjutan usaha penangkapan udang mantis sangat ditentukan manajemen penangkapan itu sendiri. Di dalam manajemen penangkapan terdapat beberapa faktor yang menentukan, seperti alat tangkap, armada penangkapan dan alat bantu; penentuan musim dan daerah penangkapan ikan; pengaturan ukuran dan komposisi hasil tangkapan; kestabilan harga jual ditingkat nelayan dan pedagang, serta pencegahan kemungkinan terjadinya konflik dengan usaha penangkapan lainnya. Kajian tentang udang mantis dan teknologi penangkapan sudah dilakukan, seperti kelimpahan dan komposisi ukuran di perairan penangkapan yang berbeda (Dini et $a l ., 2013$ ) dan pengaruh lama pengoperasian alat tangkap jaring terhadap hasil tangkapan (Popi et al., 2016). Akan tetapi, penelitian dari segi nilai finansial dan potensi konflik usaha penangkapan udang mantis tersebut belum pernah dilakukan sebelumnya. Terutama dilihat dari sisi dampak negatif yang dapat menjadi ancaman terhadap kelestarian organisme udang mantis atau biota lainnya, lingkungan maupun terhadap kehidupan sosial masyarakat apabila dilakukan secara berlebihan (over eksploitasi) serta tidak mengindahkan kaidah-kaidah penangkapan ramah lingkungan.

Berdasarkan ulasan tentang kondisi di atas, hal yang menarik dan penting untuk dilakukan penelitian di Kuala Tungkal bahwa nilai finansial yang tinggi dari penangkapan udang mantis masih memiliki potensi terjadinya konflik di kalangan nelayan. Selain itu sampai saat ini belum ada penelitian yang memastikan berapa nilai finansial dari penangkapan udang mantis serta potensi konflik dari aktivitas penangkapan tersebut. Oleh karena itu, penelitian ini bertujuan untuk menduga nilai finansial udang mantis dan menjelaskan potensi konflik dari usaha penangkapan udang mantis terhadap nelayan lainnya yang dilihat dari segi hasil tangkapan, area penangkapan serta aspek sosial dari nelayan di Kuala Tungkal, Kabupaten Tanjung Jabung Barat, Provinsi Jambi.

\section{METODE PENELITIAN}

Kegiatan penelitian dilakukan selama bulan Desember 2018. Data primer didapatkan dengan melakukan wawancara serta penyebaran kuesioner terhadap nelayan 
udang mantis dan nelayan komoditas perikanan lainnya di Kuala Tungkal. Sedangkan data sekunder berupa nilai ekspor udang mantis diperoleh dari Badan Karantina Ikan dan Pengendalian Mutu (BKIPM) Provinsi Jambi. Penangkapan udang mantis dilakukan sepanjang tahun dan tidak mengenal musim, sehingga hasil tangkapan setiap bulan relatif sama (Ramdhani et al., 2019). Tanjung Jabung Barat, Desa Kuala Tungkal, Provinsi Jambi merupakan pusat ekspor udang mantis terbesar ke berbagai negara. Oleh karena itu, penelitian dilakukan di Kuala Tungkal, Kabupaten Tanjung Jabung Barat, Provinsi Jambi (Figure 1).

Pengumpulan data nilai finansial dan hasil tangkapan dilakukan dengan wawancara, sedangkan data ketergangguan secara sosial di kalangan nelayan dilakukan dengan penyebaran kuesioner. Responden berjumlah 82, yang terdiri dari nelayan udang mantis sebanyak 18 orang (nilai finansial), nelayan togok sebanyak 22 orang, nelayan trawl mini sebanyak 28 orang dan nelayan jaring ikan sebanyak 14 orang (hasil tangkapan dan ketergangguan secara sosial). Data nilai finansial yang diambil dari nelayan udang mantis dilakukan dengan wawancara secara langsung terkait dengan biaya tetap, biaya operasional dan pendapatan dalam setiap trip penangkapan. Pengambilan data wawancara secara langsung ini dapat menghasilkan data yang representatif untuk menggambarkan nilai finansial yang sebenarnya dari penangkapan udang mantis. Nilai finansial secara keseluruhan diperoleh dari hasil tangkapan udang mantis yang di ekspor ke berbagai negara dari Badan Karantina Ikan dan Pengendalian Mutu (BKIPM) Provinsi Jambi. Data mengenai kawasan penangkapan didapatkan dari nelayan dengan berbagai alat tangkap yang berbeda, yaitu dengan cara penandaan koordinat menggunakan GPS pada masingmasing wilayah penangkapan. Data yang ditampilkan berupa koordinat perairan penangkapan dari berbagai alat tangkap yang diperoleh selama penelitian.

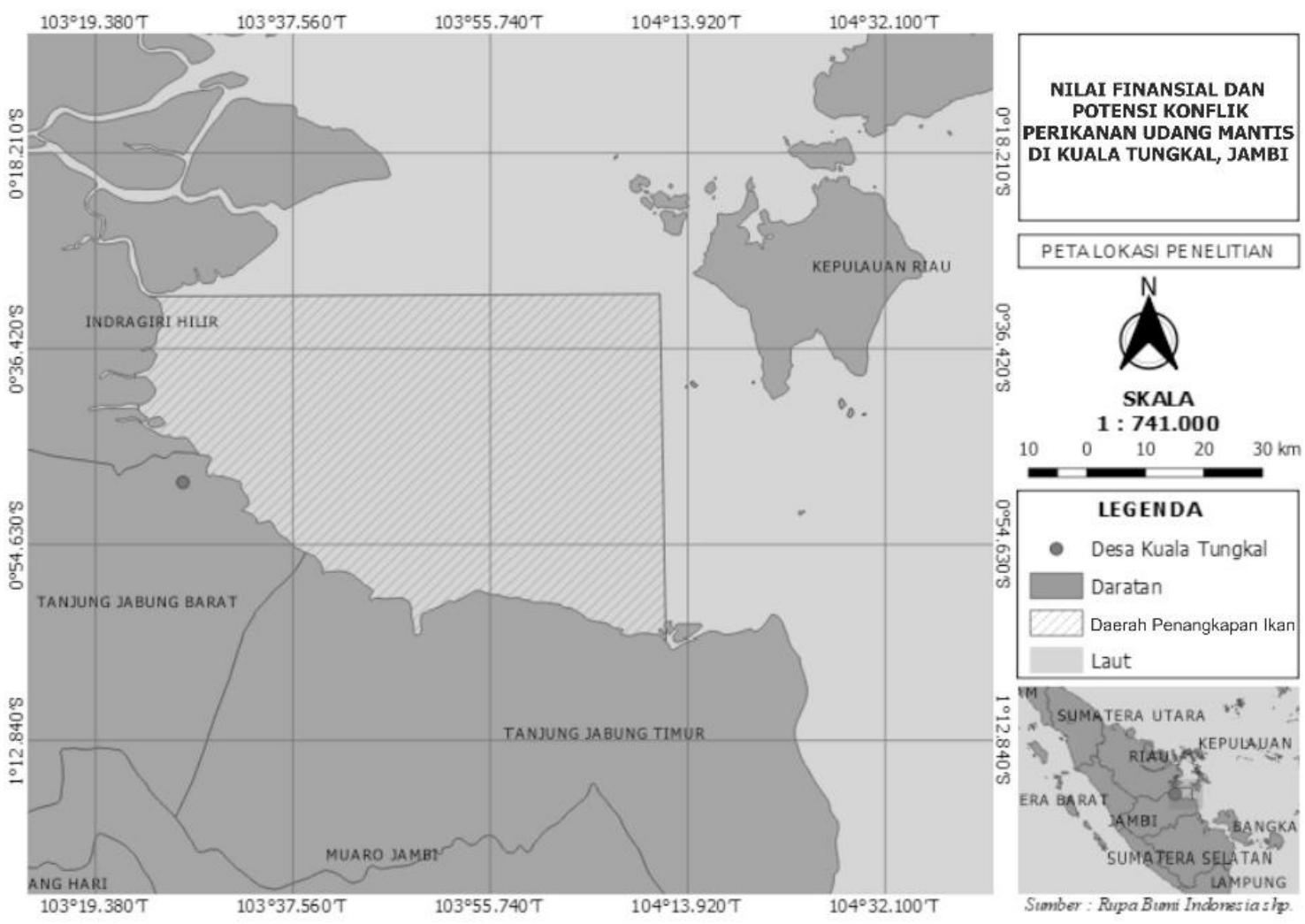

Figure 1. Research location. 
Analisis usaha secara umum ditetapkan dengan tujuan untuk menilai manfaat investasi terhadap suatu usaha yang akan dilakukan, membandingkan tingkat manfaat investasi terhadap suatu usaha dengan usaha lainnya, dengan persamaan $\pi=$ TR-TC (Gerba et al., 2014) untuk $\pi$ adalah keuntungan, $T R$ merupakan nilai total penerimaan, dan $T C$ adalah total biaya. Analisis revenue-cost ratio dilakukan untuk mengetahui seberapa jauh nilai rupiah biaya yang digunakan dalam usaha dapat memberikan sejumlah nilai penerimaan sebagai manfaatnya, dengan menggunakan persamaan $R / C=T R / T C$ (Yafiz et al., 2009). Selanjutnya analisis payback period dilakukan untuk melihat lama pengembalian investasi (initial cash investment) dengan menggunakan aliran kas dengan persamaan payback period $=$ investasi $/$ keuntungan (Tangke, 2011).

Data potensi konflik terdiri dari hasil tangkapan nelayan non udang mantis serta ketergangguan secara sosial dikalangan nelayan dan dianalisis secara deskriptif. Data lokasi penangkapan nelayan non udang mantis merupakan koordinat berupa titik (point) penangkapan yang akan diubah ke dalam bentuk raster, selanjutnya diubah ke dalam bentuk polygon. Data tersebut akan dianalisis secara deskriptif dan ditampilkan dalam bentuk peta dan gambar.

\section{HASIL DAN PEMBAHASAN}

Indonesia sebagai Negara Kepulauan, secara fisik laut menjadi faktor dominan (70\%) dan memiliki potensi yang sangat besar. Di wilayah lautan ini terkandung potensi ekonomi kelautan yang sangat besar dan beragam, antara lain sumber daya ikan (Retnowati, 2011). Nilai finansial merupakan salah satu faktor yang sangat penting dalam suatu usaha penangkapan, karena faktor ini akan berkaitan secara langsung dengan kemungkinan keuntungan atau kerugian dalam suatu usaha penangkapan ikan. Usaha penangkapan ikan pada dasarnya memiliki risiko terjadinya kerugian finansial yang disebabkan oleh faktor produksi yaitu hasil tangkapan rendah dan tidak sesuai dengan modal, maupun faktor sumber daya manusia yang belum mampu melakukan kegiatan penangkapan dengan baik (Lindawati \& Rahadian, 2016).

Usaha penangkapan udang mantis di Kuala Tungkal telah menjadi mata pencaharian utama bagi nelayan setempat. Usaha penangkapan tersebut termasuk kedalam usaha penangkapan nelayan skala kecil. Hal tersebut mengacu pada salah satu teknologi yang digunakan yaitu kapal yang berukuran 5,9 GT, dimana menurut Vibriyanti (2014) nelayan kecil adalah nelayan yang menggunakan kapal berukuran 1-10 GT.

Perikanan gillnet skala kecil memiliki kawasan penangkapan yang tidak terlalu luas yaitu jarak antara fishing base ke fishing ground tidak begitu jauh dan dilakukan secara one day fishing (Hutchings \& Lamberth, 2003), selain itu perikanan gillnet skala kecil juga menggunakan kapal yang berukuran 1-10 GT yang dapat beroperasi di sekitar area yang masih terjangkau dari pantai atau muara (Tzanatos et al., 2007). Wilayah pesisir dan lautan mempunyai peranan penting sebagai sumber penghidupan bagi nelayan setempat (Choeronawati et al., 2019). Pemanfaatan sumber daya yang tidak terlalu jauh dari wilayah perisir atau muara secara langsung akan berpengaruh terhadap penurunan biaya operasional dari usaha penangkapan yang masih cenderung rendah (Table 1).

Jumlah nelayan yang berprofesi sebagai nelayan udang mantis sebanyak 253 orang (Dinas Perikanan Kabupaten Tanjung Jabung Barat, 2018). Kebutuhan utama dalam setiap upaya penangkapan adalah terdiri dari kapal dan jaring (gillnet). Kapal yang digunakan dengan alat tangkap gillnet ini adalah pompong atau motor tempel (outboard) dengan kekuatan 5,5 PK dan berbahan bakar solar. Kapal tersebut terbuat dari kayu dengan rata-rata memiliki panjang 
$8,8 \mathrm{~m}$, lebar $1,7 \mathrm{~m}$ dan tinggi $1,6 \mathrm{~m}$. Alat tangkap gillnet dengan mesh size $10 \mathrm{~cm}$ dioperasikan oleh 2 orang dengan lama trip satu hari (one day fishing). Biaya produksi merupakan seluruh beban keuangan yang dikeluarkan oleh pelaku usaha agar dapat menjalankan kegiatan usaha untuk menghasilkan suatu output (Chrisdiyanti \& Yuliawati, 2018). Dalam melakukan usaha penangkapan udang mantis nelayan harus mengeluarkan biaya tetap serta biaya operasional dengan nilai rata-rata (Table 1).

Biaya tetap (investasi) yang dikeluarkan pada usaha penangkapan udang mantis termasuk wajar dalam perikanan gillnet skala kecil pada umumnya. Pada perikanan gillnet lainnya nelayan harus mengelurakan rata-rata modal sebesar Rp24.100.000,00 (Yafiz et al., 2009). Dengan demikian tidak terjadi pemborosan/ kelebihan biaya dalam pengeluaran modal sehingga akan menunjang aspek finansial dalam usaha penangkapan.
Sistem bagi hasil tangkapan (pendapatan) yang mempertimbangkan aset produksi dengan orang yang bekerja dalam proses produksi mulai dikenal setelah sistem mata pencaharian berkembang dan mengakui adanya hak milik perorangan, serta mempertimbangkan investasi perorangan dalam usaha penangkapan ikan (Wahyono, 2003). Pembagian pendapatan pada usaha penangkapan ikan sudah lumrah terjadi di kalangan nelayan, seperti halnya pembagian pendapatan bersih pada nelayan Pajeko (mini purse seine) dengan persentase pembagian $50 \%$ berbanding $50 \%$ antara pemilik kapal dengan anak buah kapal (ABK) (Darma et al., 2010). Pada penangkapan udang mantis, operasi penangkapan dilakukan oleh 2 orang yang terdiri dari pemilik kapal (nelayan utama) dan anak buah kapal (ABK). Pembagian pendapatan dari setiap upaya penangkapan yang dilakukan dibagi menjadi 2 bagian (nelayan utama dan $\mathrm{ABK}$ ) (Figure 2).

Table 1. Average of fixed costs and operational costs of the mantis shrimp business in Kuala Tungkal, Tanjung Jabung Barat Regency.

\begin{tabular}{cllll}
\hline No. & \multicolumn{2}{c}{ Average Fixed Cost (investment) } & \multicolumn{2}{c}{ Average Operating Cost } \\
\hline 1 & Ship & $\operatorname{Rp~} 13.000 .000,00$ & Solar & $\mathrm{Rp} 90.000,00$ \\
2 & Machine & $\mathrm{Rp} 6.000 .000,00$ & Bait & $\mathrm{Rp} 60.000,00$ \\
3 & Net & $\mathrm{Rp} 7.500 .000,00$ & Consumtion & $\mathrm{Rp} \mathrm{50.000,00}$ \\
\hline \multicolumn{2}{l}{ Total } & $\operatorname{Rp} 26.500 .000,00$ & Total & $\mathrm{Rp} \mathrm{200.000,00}$ \\
\hline
\end{tabular}

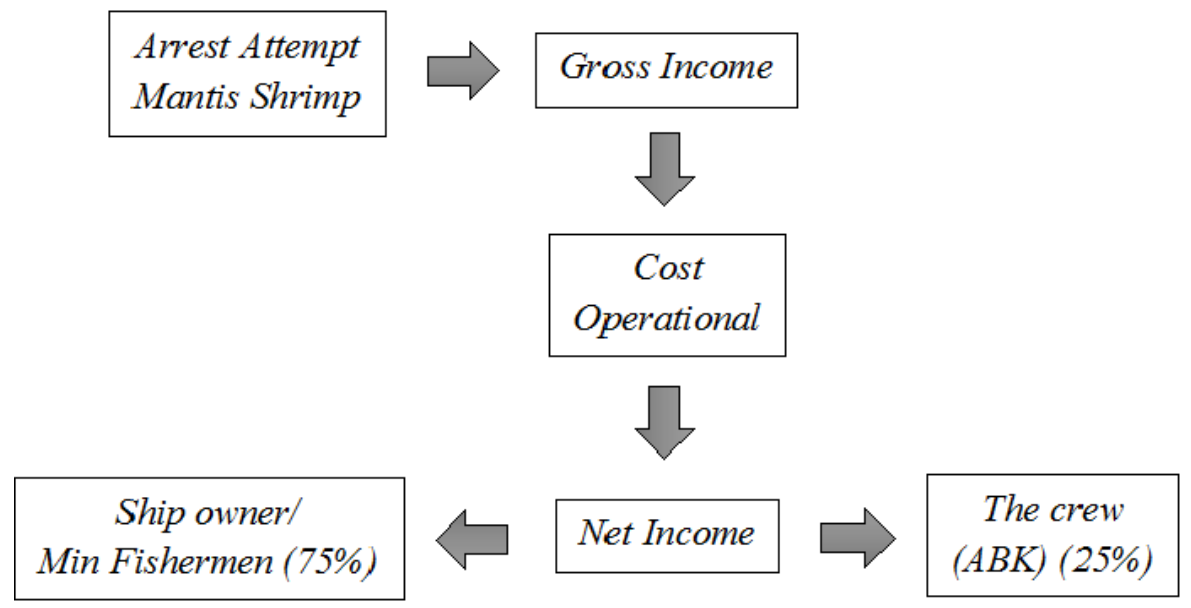

Figure 2. Profit sharing system for catching mantis shrimp. 
Rata-rata keuntungan $(\pi)$ yang diperoleh pada setiap upaya penangkapan udang mantis sebesar Rp850.000,00 dengan pembagian pemilik kapal sebesar $75 \%$ (Rp637.500,00) dan anak buah kapal (ABK) sebesar $\quad 25 \% \quad(\mathrm{Rp} 212.500,00) . \quad \mathrm{R} / \mathrm{C}$ merupakan perbandingan antara total penerimaan dengan total biaya. Pada usaha penangkapan udang mantis ini diperoleh $\mathrm{R} / \mathrm{C}>1$, sehingga dapat diartikan usaha tersebut menguntungkan dengan nilai $\mathrm{R} / \mathrm{C}$ adalah 5,6 yang berarti bahwa setiap satu rupiah total biaya yang dikeluarkan pada setiap upaya penangkapan udang mant is akan menghasilkan total penerimaan sebesar Rp4.6,00. Nilai R/C yang dimiliki oleh penangkapan udang mantis tergolong tinggi, hal ini sebanding dengan perikanan gillnet lainnya yang memiliki hasil tangkapan berbeda dengan nilai R/C 7,01 (Yafiz et al., 2009). Berdasarkan nilai tersebut maka usaha penangkapan udang mantis ini menguntungkan secara finansial bagi para pelaku usaha dan memiliki potensi untuk terus dikembangkan. PP dalam studi kelayakan usaha berfungsi untuk mengetahui berapa lama usaha yang diusahakan dapat mengembalikan investasi. Semakin cepat pengembalian biaya investasi sebuah usaha, semakin baik usaha tersebut karena semakin lancar perputaran modal. PP dari usaha penangkapan udang mantis di Kabupaten Tanjung Jabung Barat adalah 39 trip penangkapan. Hal ini berarti waktu yang dibutuhkan untuk pengembalian biaya dan modal investasi dalam waktu cukup pendek yakni pada trip ke 39 yaitu trip penangkapan udang mantis (Table 2).

Table 2. Analysis of mantis shrimp business in Kuala Tungkal, Tanjung Jabung Barat Regency.

\begin{tabular}{ll}
\hline \multicolumn{1}{c}{ Business Analysis } & \multicolumn{1}{c}{ Outcome } \\
\hline ( $\pi$ ) (Profit) Net of & $\mathrm{Rp} \mathrm{637.500,00}$ \\
shipowners & 5.6 \\
Revenue cost ratio $(\mathrm{R} / \mathrm{C})$ & 39 trips \\
Payback period $(\mathrm{PP})$ & . \\
\hline
\end{tabular}

Keseluruhan analisis usaha penangkapan menunjukkan bahwa usaha penangkapan udang mantis di Kuala Tungkal memiliki nilai finansial yang baik. Pendapatan nelayan dipengaruhi oleh banyak atau tidaknya hasil tangkapan udang mantis yang diperoleh. Dengan melakukan upaya penangkapan yang ramah lingkungan (tidak merusak hasil tangkapan), maka nilai finansial dari usaha penangkapan tersebut dapat dipertahankan bahkan ditingkatkan.

Nilai ekspor udang mantis secara keseluruhan di Kuala Tungkal, dalam kurun waktu 2015-2017 cenderung terjadi peningkatan. Tahun 2015 volume ekspor sebanyak 2.488 .867 ekor meningkat $27,14 \%$ pada tahun 2016 menjadi 3.164.420 ekor dan pada tahun 2017 meningkat 19,61\% menjadi 3.785.059 ekor (BKIPM Jambi, 2018). Kondisi tersebut menunjukkan bahwa keberadaan suatu organisme hasil tangkapan di perairan relatif stabil (Catchpole et al., 2004). Selain itu peningkatan volume ekspor disebabkan oleh jumlah penangkapan udang mantis yang semakin bertambah dan kebiasaan nelayan melakukan penangkapan berbagai ukuran yang tidak selektif mulai dari ukuran kecil, sedang, besar dan dalam kondisi bertelur (Sukarni et al., 2018). Kegiatan ekspor udang mantis dilakukan melalui Stasiun Karantina Ikan dan Pengendalian Mutu (SKIPM) Jambi (Figure 3). Data tersebut menunjukkan ketersediaan udang mantis di perairan yang melimpah serta jumlah penangkapan yang terus bertambah sehingga terjadi peningkatan volume hasil tangkapan nelayan yang diekspor ke berbagai negara (Sukarni et al., 2018). Hasil tangkapan tersebut disertifikasi di SKIPM Jambi. Udang mantis dikirim melalui bandara Sultan Thaha ke Jakarta, selanjutnya di ekspor ke berbagai negara. Udang mantis belum bisa diekspor langsung dari Jambi karena dari bandara Sultan Thaha Jambi belum ada penerbangan internasional (Sukarni et al., 2018). Meski demikian kondisi tersebut tetap sangat menguntungkan dan berdampak positif terhadap peningkatan 
pendapatan masyarakat khususnya di sekitar Tanjung Jabung Barat. Nilai komoditas udang mantis yang di ekspor pada tahun 2015 senilai Rp49.777.340.000,00 pada tahun 2016 meningkat $21,3 \%$ menjadi Rp63.288.400.000,00 sedangkan pada tahun 2017 meningkat secara signifikan 76,1\% menjadi Rp264.954.130.000,00 (Figure 4).

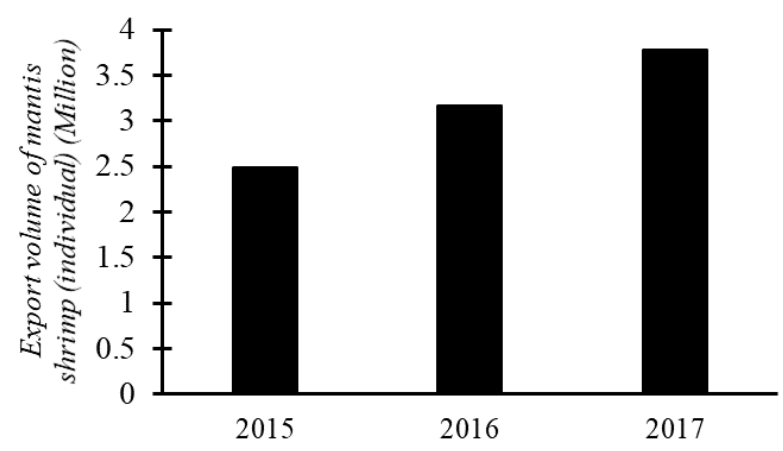

Figure 3. Volume of mantis shrimp commodity out through Jambi Fish Quarantine and Quality Control Station (SKIPM) from 2015 to 2017.

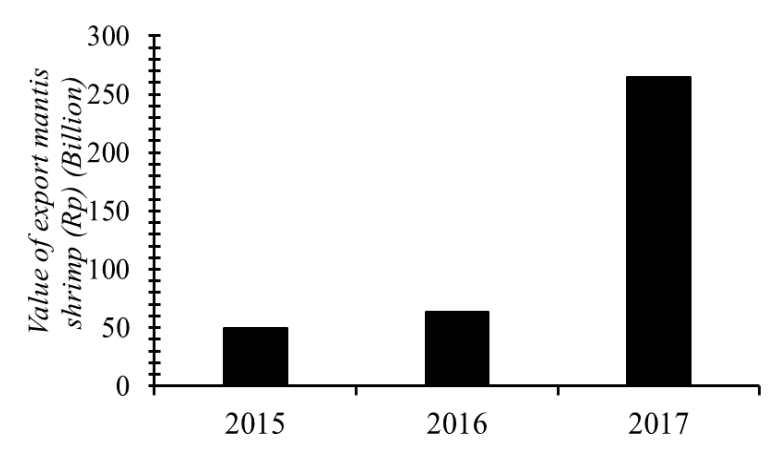

Figure 4. Value of mantis shrimp commodity out through the Fish Quarantine and Quality Control Station (SKIPM) Jambi from 2015 to 2017.

Interaksi sistem sosial-ekologi di kawasan pesisir sering menimbulkan permasalahan, salah satunya adalah terjadinya konflik sosial (Muliani et al., 2018). Konflik yang terjadi pada perikanan gillnet tidak hanya terbatas pada perikanan gillnet skala besar, melainkan perikanan gillnet skala kecil memiliki potensi konflik yang sama (Hutchings \& Lamberth, 2003). Sebagian besar konflik yang terjadi berasal dari fakta bahwa spesies utama yang menjadi target tangkapan banyak tertangkap oleh alat tangkap lain sebagai hasil tangkapan sampingan (bycatch). Selain itu ikan-ikan tersebut memiliki nilai yang penting bagi perikanan komersial dan memiliki fungsi bagi ekosistem perairan (Gray \& Kennelly, 2003). Alat tangkap yang beroperasi di perairan Kuala Tungkal terdiri dari 4 jenis, yaitu pukat kecil (trawl mini), jaring insang (gillnet) untuk udang mantis, togok dan jaring insang (gillnet) untuk ikan (Dinas Perikanan Kabupaten Tanjung Jabung Barat, 2018). Masing-masing dari alat tangkap tersebut memiliki target hasil tangkapan utama yang berbeda-beda (Table 3).

\section{Table 3. Main catches of various fishing} equipment in Kuala Tangkal, Tanjung Jabung Barat District.

\begin{tabular}{ll}
\hline \multicolumn{1}{c}{ Catching Tools } & \multicolumn{1}{c}{ Main Catches } \\
\hline Trawl mini & Various types of \\
& shrimp and Bawal fish \\
Gillnet fish & Senangin fish, \\
& Tongkol fish \\
Togok & Shrimp (rebon)/ \\
& Pepay shrimp \\
\hline
\end{tabular}

Source: Interview results

Berdasarkan pengamatan di lapangan tidak ditemukan adanya udang mantis yang menjadi hasil tangkapan sampingan pada alat tangkap lainnya, juga tidak ditemukan hasil tangkapan utama alat tangkap lain yang tertangkap oleh nelayan udang mantis, sehingga kondisi tersebut memiliki potensi konflik cenderung rendah yang disebabkan adanya hasil tangkapan utama pada suatu alat tangkap yang menjadi bycatch dan discard pada alat tangkap lainnya.

Pada dasarnya prinsip pengelolaan sumberdaya perikanan di Indonesia telah diatur jelas pada Undang-Undang Dasar 1945 pasal 33 (dikenal dengan sistem pengelolaan bersifat state property), sehingga sumberdaya perikanan di Indonesia 
bersifat quasi open access (Annisa et al., 2009). Dengan demikian kesamaan ruang atau wilayah penangkapan berpotensi menyebab-kan terjadinya konflik, sebab adanya perairan penangkapan yang sama namun digunakan untuk pemanfaatan hasil tangkapan berbeda dengan berbagai alat yang berbeda. Pemakaian alat tangkap yang berbeda maka memiliki cara pengoperasian alat tangkap yang berbeda, yang memungkinkan adanya gangguan pengoperasian alat tangkap satu ke alat tangkap lainnya (Hutchings \& Lamberth, 2003). Pada penelitian ini didapatkan titik dari 3 alat tangkap yang beroperasi di lokasi penelitian, yaitu jaring ikan, jaring udang mantis dan togok sedangkan perairan penangkapan untuk alat tangkap trawl mini belum berhasil diketahui pada penelitian ini (Figure 5).
Faktor lain yang menyebabkan adanya konflik di nelayan adalah aspek sosial antara pengguna alat tangkap yang berbeda. Konflik sosial pernah terjadi di tempat pelelangan ikan di Brondong, Kabupaten Lamongan, Jawa Timur pada tahun 1998. Konflik ini disebabkan oleh perubahan alat tangkap yang bersifat tradisional ke alat tangkap yang bersifat modern, sehingga berpengaruh terhadap produktivitas hasil melaut dan ketergangguan penggunaan alat tangkap serta kecemburuan hasil tangkapan antara alat tangkap tradisonal dan alat tangkap modern (Jannah, 2013).

Sementara itu di Kuala Tungkal, hasil penyebaran kuesioner terhadap 64 responden (22 orang nelayan togok, 28 orang nelayan trawl mini, dan 14 orang nelayan jaring ikan) menunjukkan bahwa pelaksanaan usaha penangkapan udang mantis tidak berdampak

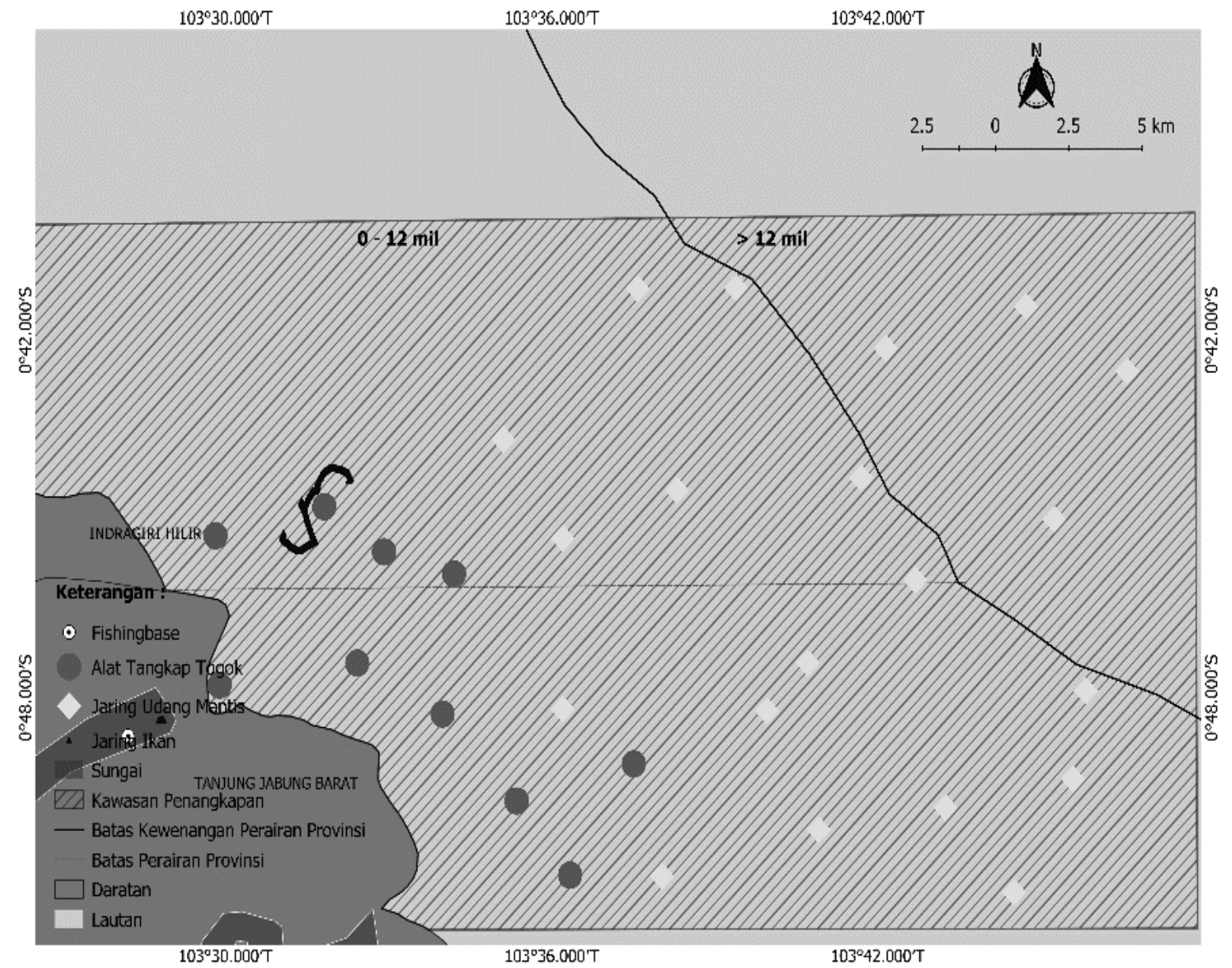

Figure 5. Distribution of several types of the fishing gear at the study site. 
signifikan terhadap aktivitas nelayan dengan alat tangkap lain, sebesar $69 \%$ nelayan responden merasa tidak terganggu. Hal ini mengindikasikan bahwa usaha penangkapan udang mantis dan usaha penangkapan dengan alat tangkap lain dapat dilaksanakan secara bersamaan di perairan (Figure 6).

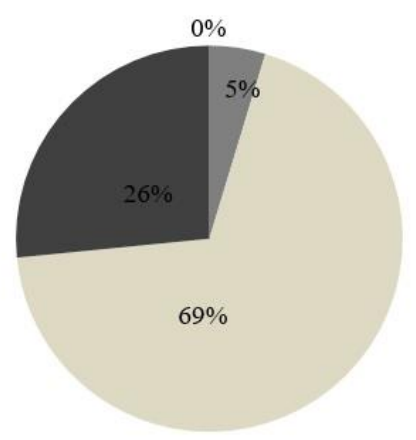

- Very disturbed

- Disturbed

Not disturbed

- Very undisturbed

Figure 6. Percentage of disturbance felt by nonfishermen catching mantis shrimp.

Perolehan hasil tangkapan pada alat tangkap lain menunjukkan hasil tangkapan yang tidak berkurang (52\%) dan berkurang (48\%), hal tersebut menunjukkan perolehan hasil tangkapan cenderung berbeda pada setiap nelayan yang melalukan upaya penangkapan ikan (Figure 7).

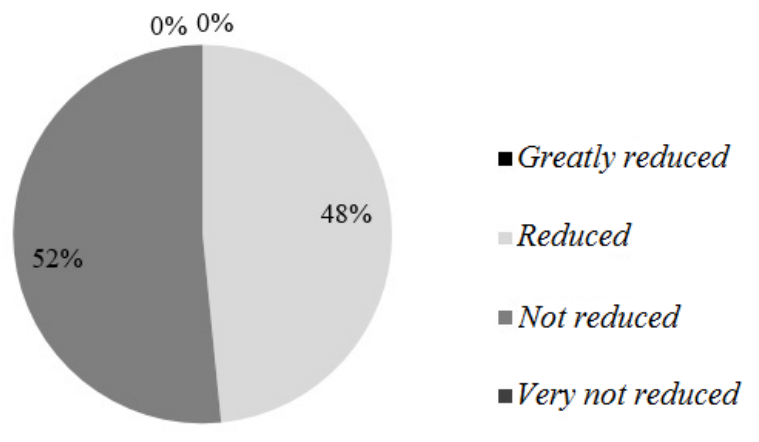

Figure 7. Percentage of acquisition results
current catches from non-
fishermen catching mantis shrimp.

Perolehan hasil tangkapan pada alat tangkap lain sebagian besar tidak mengalami penurunan akibat dari adanya usaha penangkapan udang mantis karena sumberdaya yang ditangkap berbeda. Hal tersebut menunjukkan bahwa penangkapan udang mantis tidak memiliki pengaruh yang signifikan terhadap hasil tangkapan pada alat tangkap lain (Figure 8).

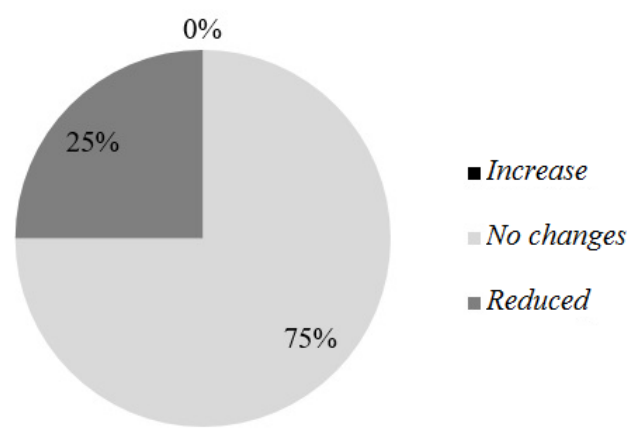

Figure 8. Percentage of change in catch of other fishing gear after mantis shrimp catch.

Metode pengoperasian alat tangkap pada dasarnya dapat mempengaruhi hasil tangkapan alat tangkap lain, sehingga menjadi pemicu terjadinya konflik dikalangan nelayan. Seperti yang terjadi pada nelayan Desa Lekok dan Desa Kwanyar Kabupaten Bangkalan, Madura yang disebabkan oleh perbedaan metode pengoperasian alat tangkap (Annisa et al., 2009).

Hasil wawancara di lokasi penelitian menunjukkan bahwa usaha penangkapan udang mantis tidak memberikan gangguan yang signifikan tehadap jumlah hasil tangkapan dan pendapatan nelayan dengan alat tangkap lain. Adapun selang hasil tangkapan dan rata-rata pendapatan nelayan yang menggunakan alat tangkap lain disajikan pada Table 4.

Hasil keseluruhan wawancara nilai finansial dan hasil tangkapan serta penyebaran kuesioner ketergangguan secara sosial dikalangan nelayan menunjukkan bahwa potensi konflik yang mungkin ditimbulkan dari usaha penangkapan udang mantis terhadap alat tangkap lainnya cenderung rendah, baik dari segi hasil tangkapan, area penangkapan maupun aspek sosial. 
Table 4. The average of catches and income of fishermen in Kuala Tungkal, West Tanjung Jabung Regency.

\begin{tabular}{lccc}
\hline \multicolumn{1}{c}{ Catching Tools } & $\begin{array}{c}\text { Catch Hose Interval } \\
\text { kg/day }\end{array}$ & $\begin{array}{c}\text { Average Revenue } \\
\text { per day }\end{array}$ & $\begin{array}{c}\text { Average Revenue } \\
\text { per month }\end{array}$ \\
\hline Togok & $5-15$ & $\mathrm{Rp} 230.000,00$ & $\mathrm{Rp} 6.400 .000,00$ \\
Trawl mini & $250-320$ & $\mathrm{Rp} 580.000,00$ & $\mathrm{Rp} 9.000 .000,00$ \\
Gillnet fish & $18-24$ & $\mathrm{Rp} 380.000,00$ & $\mathrm{Rp} 7.500 .000,00$ \\
\hline
\end{tabular}

Source: Interview

Sehingga penangkapan udang mantis bisa dilakukan bersamaan dengan penangkapan komoditas dan alat tangkap lainnya di Kuala Tungkal, Kabupaten Tanjung Jabung Barat, Provinsi Jambi.

\section{KESIMPULAN}

Berdasarkan hasil penelitian disimpulkan bahwa nilai finansial dari perikanan udang mantis tergolong layak diusahakan dan dikembangkan serta memiliki potensi yang rendah untuk terjadinya konflik dengan nelayan yang menggunakan alat tangkap lain di Kuala Tungkal, Kabupaten Tanjung Jabung Barat, Provinsi Jambi.

\section{UCAPAN TERIMA KASH}

Ucapan terima kasih disampaikan kepada nelayan udang mantis dan Dinas Perikanan Kabupaten Tanjung Jabung Barat yang telah banyak memberikan bantuan selama pengumpulan data di lapangan.

\section{DAFTAR PUSTAKA}

Annisa, L., A. Satria, \& R.A. Kinseng. 2009. Konflik nelayan di Jawa Timur: Studi kasus perubahan struktur agraria dan diferensiasi kesejahteraan komunitas pekebun di Lebak, Banten. $J$. Sosiologi Pedesaan, 3(1): 113-124. https://doi.org/10.22500/sodality.v3i1 .5870

Balai Karantina Ikan, Pengendalian Mutu, dan Keamanan Hasil Perikanan
(BKIPM) Jambi. 2018. Nilai ekspor udang mantis dalam angka. Nilai Ekspor Udang Mantis dalam Angka. Jambi. 16 p.

Catchpole, T.L., C.L.J Frid, \& T.S. Gray. 2004. Discarding in the English north-east coast Nephrops norvegicus fishery: The role of social and environmental factors. Fisheries Research, 72: 45-54.

http://doi.org/10.1016/j.fishres.2004.1 0.012

Choeronawati, A.I., S.B. Prayitno, \& Haerudin. 2019. Studi kelayakan budidaya tambak di lahan pesisir Kabupaten Purworejo. J. Ilmu dan Teknologi Kelautan Tropis, 11(1): 191-204.

https://doi.org/10.29244/jitkt.v11i1.22 522

Chrisdiyanti, Y.K. \& Yuliawati. 2018. Analisis pendapatan usaha tani dan faktor-faktor yang mempengaruhi risiko produksi bunga potong krisan di Desa Duren Kecamatan Bandungan. J. Agrikan, 12(1): 1-7. https://doi.org/10.29239/j.agrikan.12. 1.1-7

Dahuri, R. 2003. Keanekaragaman hayati laut: Aset pembangunan berkelanjutan Indonesia. PT Gramedia Pustaka Utama. Jakarta. 412 p.

Darma, S., B. Wiryawan, \& T.W. Nurani. 2010. Analisis keragaman usaha penangkapan ikan pasca program pemberdayaan nelayan di Kabupaten Halmahera Utara. Sekolah Pascasarjana IPB. Bogor. 20 p. 
Dinas Perikanan Kabupaten Tanjung Jabung Barat. 2018. Jumlah rumah tangga perikanan laut, alat tangkap, dan tenaga kerja perkecamatan tahun 2018. Jambi. 16 p.

Dini, L., K. Ma'ruf, \& R.D. Palupi. 2013. Kelimpahan dan komposisi ukuran panjang udang ronggeng (Lysiosquilla maculata) pada habitat yang berbeda di perairan Kauduma Desa Petetea'a Kabupaten Buton Utara. J. Mina Laut Indonesia. 01(01): 1-11.

Gerba, S.V., F. Agustriani, \& Isnaini. 2014. Analisis finansial penangkapan ikan dengan alat tangkap drift gillnet di Kecamatan Toboali Kabupaten Bangka Selatan Bangka Belitung. $J$. Maspari, 7(2): 19-24. https://doi.org/10.36706/maspari.v7i2 .2434

Gray, C.A. \& S.J. Kennelly. 2003. Catch characteristics of the commercial beach-seine fisheries in two Australian barrier estuaries. Fish. Res., 63: 405-422. https://doi.org/10.1016/S01657836(03)00076-6

Hutchings, K. \& S.J. Lamberth. 2003. Likely impacts of an eastward expansion of the inshore gill-net fishery in the Western Cape, South Africa: implications for management. Marine and Freshwater Research, 54(1): 3956.

https://doi.org/10.1071/MF01209

Jannah, R. 2013. Konflik sosial di tempat pelelangan ikan di Brondong Tahun 1998. J. Avatara, 1(1): 84-92.

Lindawati \& R. Rahadian. 2016. Identifikasi faktor dan penilaian risiko pada usaha perikanan tangkap di Kabupaten Sambas. J. Sosek KP, 11(1): 99-107. https://doi.org/10.15578/jsekp.v11i1.3 175

Moosa, M.K. 2000. Marine biodiversity of the South China Sea: A checklist of stomatopod crustacea. The Raffles Bulletin of Zoology, 8: 405-457. http://rmbr.nus.edu.sg/exanambas/rbz s8-scs/pdf/s08rbz405-457.pdf

Muliani, L. Adrianto, K. Soewardi, \& S. Hariyadi. 2018. Sistem sosial ekologi kawasan desa pesisir Kabupaten Subang. J. Ilmu dan Teknologi Kelautan Tropis, 10(3): 575-587. https://doi.org/10.29244/jitkt.v10i3.20 597

Nofrizal, R. Jhonnerie, A. Hindriyani, \& Alfin. 2018. Hasil tangkapan sampingan (bycatch) dan discard) pada alat tangkap gombang (filter net) sebagai ancaman bagi kelestarian sumberdaya perikanan. J. Marine Fisheries, 9(2): 221-233. https://doi.org/10.29244/jmf.9.2.221233

Popi, I.M.S. Lisna, \& M. Jasmine. 2016. Pengaruh waktu perendaman jaring insang dasar terhadap hasil tangkapan udang mantis (Harpiosquilla raphidea) di Kuala Tungkal Kabupaten Tanjung Jabung Barat. Repository Universitas Jambi, 1-14. http://repository.unja.ac.id/1165

Ramdhani, F., Nofrizal, \& R. Jhonnerie. 2018. Studi hasil tangkapan bycatch dan discard pada perikanan udang mantis (Harpiosquilla raphidea) menggunakan alat tangkap gillnet. J. Marine Fisheries, 10(2): 129-139.

https://journal.ipb.ac.id/index.php/jps p/article/view/29496/19207

Retnowati, E. 2011. Nelayan Indonesia dalam pusaran kemiskinan struktural (Perspektif Sosial, Ekonomi dan Hukum). J. Perspektif, 16(1): 149159.

https://doi.org/10.30742/perspektif.v1 $6 \mathrm{i} 3.79$

Rudiana, E. \& D. Pringgenies. 2004. Morfologi dan anatomi cumi-cumi Loligo divaucell yang memancarkan cahaya. J. Ilmu Kelautan, 9(2): 96100. 
https://doi.org/10.14710/ik.ijms.9.2.9 6-100

Sukarni, Rina, A. Samsudin, \& Y. Purna. 2018. Harpiosquilla raphidea, udang belalang komoditas unggulan dari Provinsi Jambi. J. Penyuluhan Perikanan dan Kelautan, 12(3): 174188. https://doi.org/10.33378/jppik.v12i3.1 08

Tangke, U. 2011. Analisis kelayakan usaha perikanan tangkap menggunakan alat tangkap gill net dan purse seine di Kecamatan Leihitu Kabupaten Maluku Tengah Provinsi Maluku. $J$. Agrikan, 4(1): 1-13. https://doi.org/10.29239/j.agrikan.4.1. $1-13$

Tzanatos, E., S. Somarakis, G. Tserpes, \& C Koutsikopoulos. 2007. Identifying and classifying small-scale fisheries me'tiers in the Mediterranean: a case study in the Patraikos Gulf, Greece. Fisheries Research, 81: 158-168. https://doi.org/10.1016/j.fishres.2006. 07.007

Vibriyanti, D. 2014. Kondisi sosial ekonomi dan pemberdayaan nelayan tangkap kota Tegal, Jawa Tengah.
Kependudukan Indonesia, 9(1): 4558.

https://doi.org/10.14203/jki.v9i1.10

Wardiatno, Y., A. Fajarallah, \& A. Mashar. 2009. Kajian aspek reproduksi dan genetika udang mantis (Harpiosquilla raphidea, fabricius 1798) di Kuala Tungkal, Kabupaten Tanjung Jabung Barat, Jambi sebagai upaya lanjutan domestikasi udang mantis. IPB. Bogor. 89 p.

Wayhono, A. 2003. Konflik bagi hasil tangkapan purse seine di Prigi, Trenggalek, Jawa Timur. $J$. Masyarakat dan Budaya, 5(1): 83-96. http://doi.org/10.14203/jmb.v5i1.260

Yafiz, M., A.F.F Sondita, S. Soemakaryo, \& R. Daniel. 2009. Analisis finansial usaha penangkapan ikan dalam model perbaikan kesejahteraan nelayan di Kabupaten Rokan Hilir Provinsi Riau. J. Perikanan dan Kelautan, 14(1): 8192.

http://doi.org/10.31258/jpk.14.01.\%2 $5 \mathrm{p}$

Received :07 September 2019

Reviewed : 20 October 2019

Accepted :25 January 2020 